\title{
Replicating a seventeenth century sword: the Storta Project
}

\author{
Giovanni Sartori,
}

Independent scholar (formerly University of Venice, Conservation Science and Technology for Cultural Heritage)

\begin{abstract}
Making a good "copy" of an ancient weapon means to reach different targets, not only regarding the final product of the making process but also the process itself. This means that to make a sword like this, it is necessary to initially study all the material regarding swords and blades from the same period and geographic area. This process involves not only their style, design, geometry, weights and balance, but also the cultural background of the period, the use and symbolism of the weapon and finally the original production techniques used. This article reviews and documents the "Storta project" in the context of a museum exhibition in Minsk (European Martial Arts: From Vulcan's Forge to the Arts of Mars, 01.05-30.09.2019).
\end{abstract}

Keywords - Storta, Coltella, Sword replication, Archaeology

This article reviews and document a research project started in 2015, which aims to display a state-of-the-art study about Renaissance sword makers and their knowledge, through the production of a museum quality replica. The output is on display of the International exhibition "European Martial Arts: From Vulcan's Forge to the Arts of Mars" (Minsk History Museum, 01.05-30.09.2019). It is based on scientific studies of original swords (Caino, early $17^{\text {th }}$ c.) conducted at the University of Brescia, and an archaeological experimental project reconstructing the process of the making in a $17^{\text {th }}$ century forge still active (Bienno (BS), Val Camonica, Italy).

\section{THE CHOICE OF A MODEL}

The weapon chosen for the project has been a storta which is part of the Martial Arts Museum's collection (Fig. 1). This beautiful sword has been made in Caino (Brescia, Italy) at the beginning of the seventeenth century and is attributed to the swordsmith Tomaso Gorgonio Desenzani, owner and master of the Terminello workshop (Fig. 2). It is most likely the most complete and genuine extant sword of its type made in Caino. 


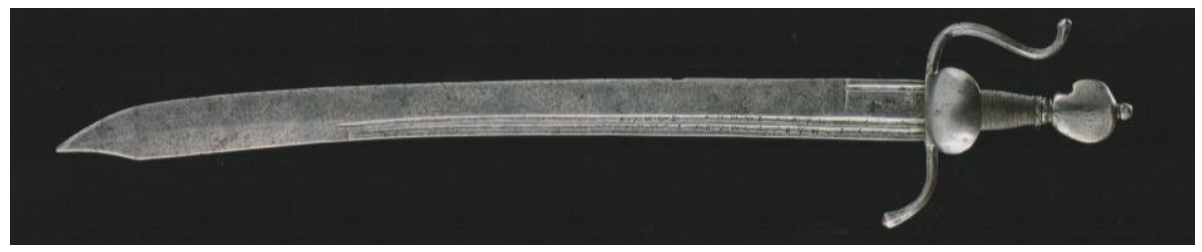

Fig. 1: The original Storta (made in Caino, beginning of 17th c.), now kept in the MAM (Martial Arts Museum, Botticino). Photo from the book Caino (Gotti, 2011).

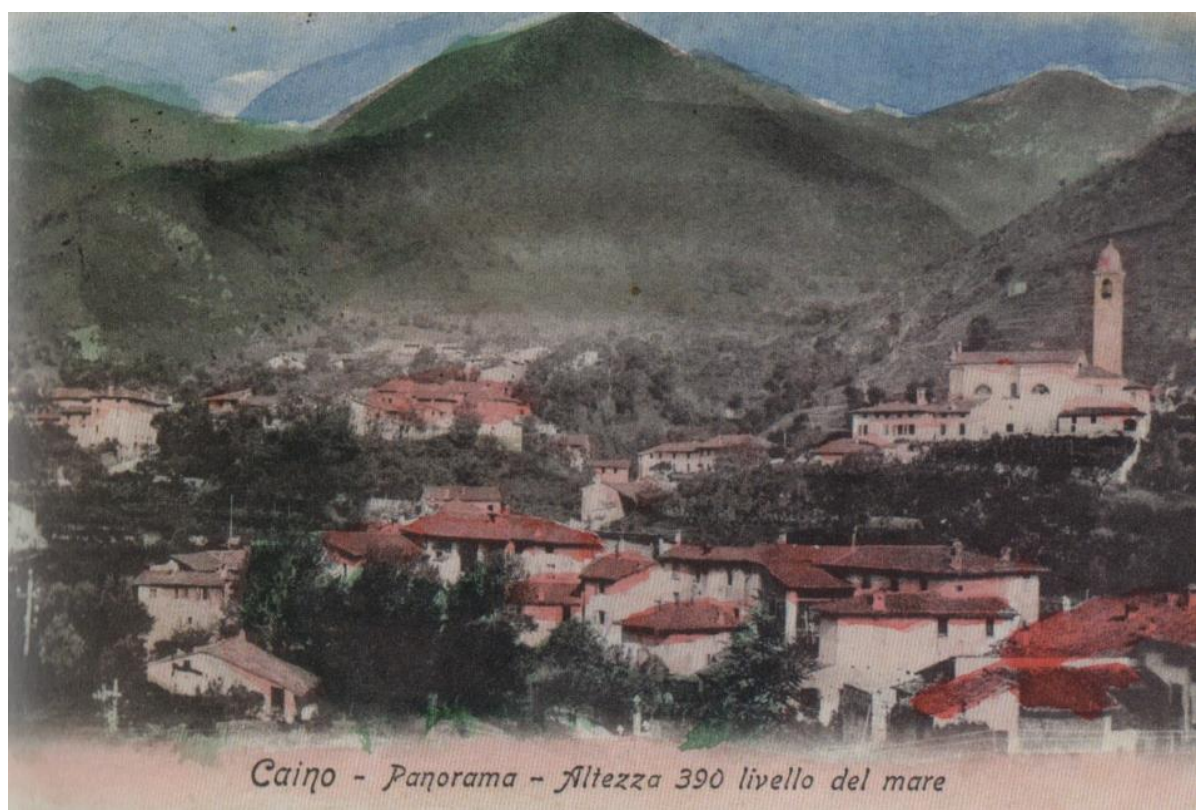

Fig. 2: Old postcard showing Caino Village. Reproduced from the book Caino (Gotti, 2011).

The blade is signed with the name F.TOMASO twelve times and of course the CAINO proof mark, with an overall length of $812 \mathrm{~mm}$, a weight of $1018 \mathrm{gr}$ and a balance point $107 \mathrm{~mm}$ from the guard. ${ }^{1}$ The reason behind the choice of this sword as a model was not only how well preserved it is, but also the possibility to use the results of a metallurgical study made in the University of Brescia on a different, broken, storta sword made in Caino as well. ${ }^{2}$

Another important reason was that the Storta was one of the most iconic weapons of the Italian renaissance (next section will shortly explain why) and a typical product of NorthItalian swordsmiths, in particular of the Brescian area. So our set target was to produce a copy of the aforementioned Caino storta as close as possible to the original not only

\footnotetext{
${ }^{1}$ Gotti, Caino, p. 158-9.
}

2 Tonelli et al., "Historical and Metallurgical Characterization of a 'Falchion' Sword". 
regarding measures, weights and balance point but also forging techniques, finishing, materials, pattern of the steel and its quality.

\section{I.1. The Storta or Coltella: some informations}

The storta belongs to the wider family of single edged weapons which includes swords from the ancient design of the seax to the boarding nineteenth-century cutlass (and many others like the falchion, the messer and the dussack). It can be considered a versatile sword for several reasons.

First, because of the versatility in the context of its use: it can be an infantry weapon for a soldier, a boarding weapon for a sailor, a useful everyday tool for a farmer, and an urban self-defence weapon for a nobleman or an artisan. Its short, single edged and large blade makes it an ideal weapon to fight in a tight space like an infantry square, a melee or a ship deck. Moreover, its use can be intuitive and can be easily learned even by a novice. From an economic point of view, making a single-edged short sword implies less time and material compared to a sidesword of the same period. So the storta is cheaper than other weapons and ideal to be an arsenal sword.

For all of the above reasons the storta has been popular in the sixteenth and seventeenth centuries and we can see this type of sword worn both by Kings, soldiers, pirates and farmers (Fig. 3). ${ }^{3}$

3 Gotti, Caino, p. 108-114. 


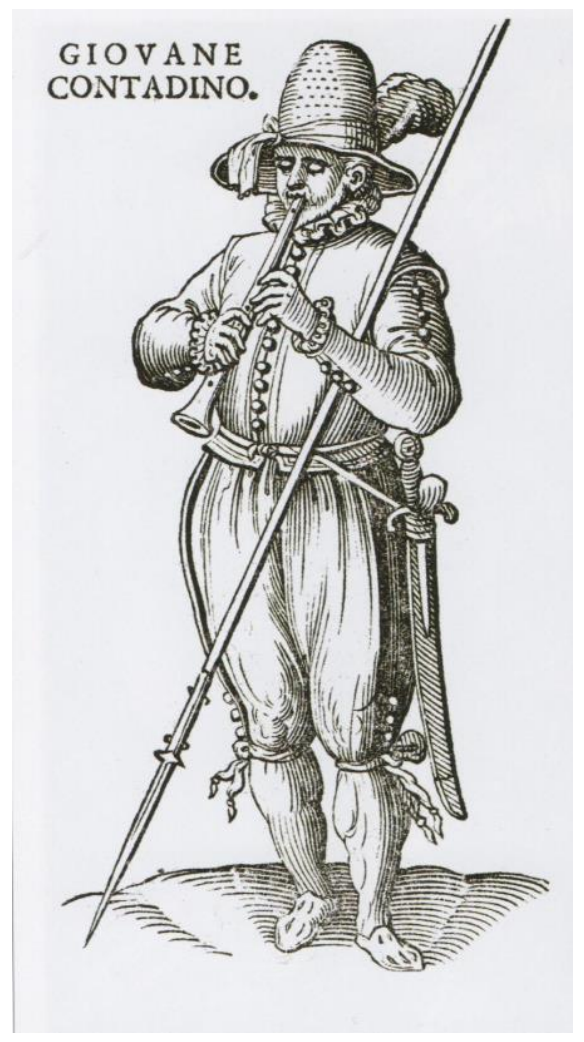

Fig.3: Engraving by Cesare Vecellio, 1590. Degli Habiti Antichi e Moderni. Venezia.

\section{THE MAKING PROCESS: APPROACH}

The storta copy has been produced following both the results of metallurgical studies ${ }^{4}$ and literature on the subject from the $16^{\text {th }}$ and $17^{\text {th }}$ centuries (Biringuccio, 1540; Petrini, 1642; Da Lezze, 1612).

In particular Catastico Bresciano the book written by Giovanni Da Lezze and published in 1612 that describes the Brescian country and his activities. In this detailed report made for the Venetian government there is a chapter about sword making which was one of the main activities of the town in that period. It is an important document because it explains the entire process of sword-making (with 13 masters listed taking part in the making process) and we have used it as a reference. The geometries of all parts (except the handle) have been done by forging; reducing, as much as possible, the loss of material during the grinding and polishing phases. Wherever we needed to respect the original construction forge welding was applied.

${ }^{4}$ Gotti, Caino; Williams, The Sword and the Crucible; Tonelli et al., "Historical and Metallurgical Characterization of a 'Falchion"'. 
Vannoccio Biringuccio in his treatise De La Pirotechnia says that a good master blacksmith gives the forms and geometry to the objects by forging and not by stock removal ${ }^{5}$ and this process appears to be confirmed by scientific research on the originals as well. Etched sections of original blades show that the steel pattern follows the geometries of the blade. In particular, on blades that have an external carbon steel layer wrapped around an iron core it is possible to notice the plastic deformation of layers done by forging. ${ }^{6}$

\section{II.1. The blade}

\section{II.1.1. Making the billet}

According to the scientific research on period blades, the blade has been made from a billet composed of layers of carbon steel and wrought iron piled and forge-welded together. ${ }^{7}$ The bulk pattern is an outer "skin" (with a V shape open on the back of the blade) with 460 alternate layers of wrought iron and carbon steel wrapped around a plain wrought iron core (Fig. 4).

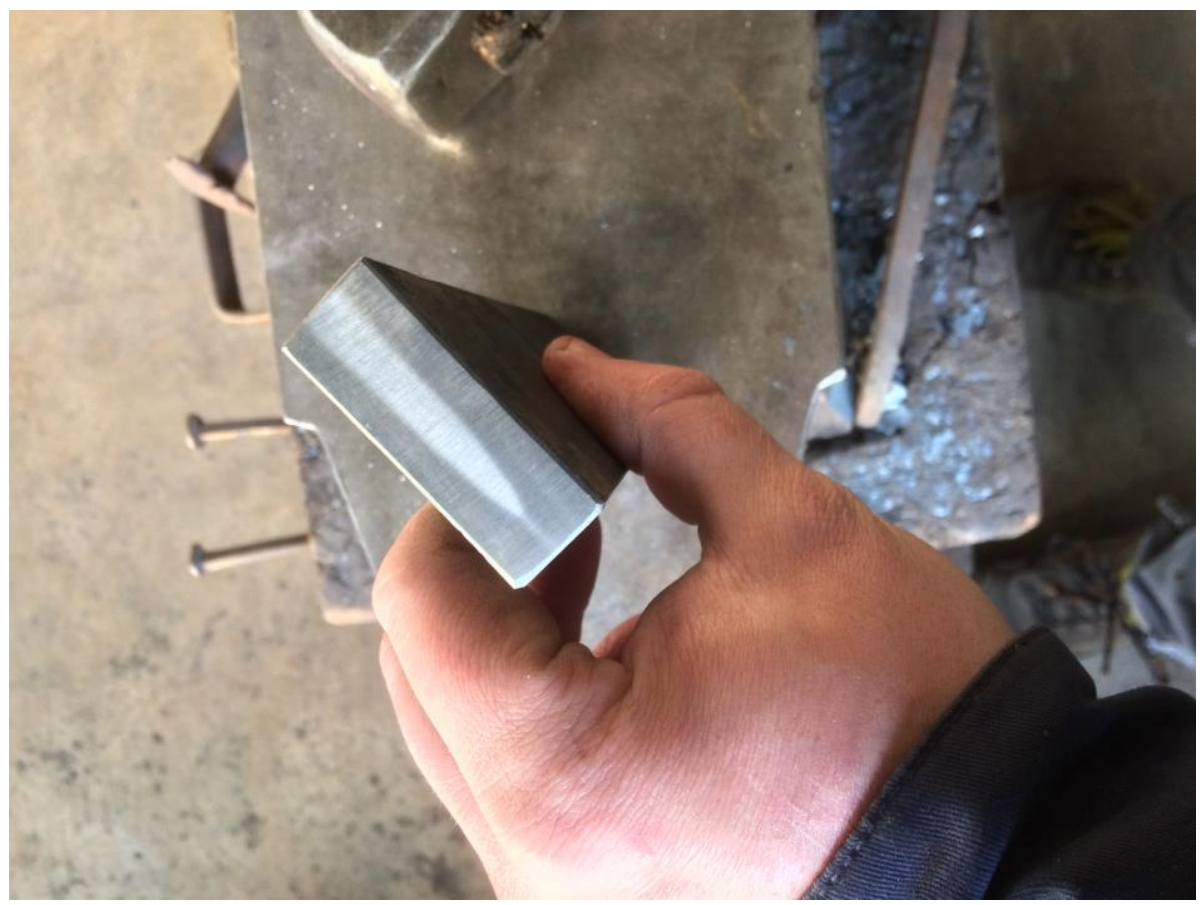

Fig. 4: Bulk. pattern of the final billet.

\footnotetext{
5 Biringuccio, De la pirotechnia, 1540, p 136-137.

${ }^{6}$ Gotti, Caino, p. 131-155; Williams, The Sword and the Crucible, p.230-285.

7 Tonelli et al., "Historical and Metallurgical Characterization of a 'Falchion' Sword"; Williams, The Sword and the Crucible, p. 230-285.
} 
The mix of many layers of wrought iron and carbon steel is described by Antonio Petrini in his treatise De l'Arte Fabrile (1642). Petrini calls the technique ammassellamento and says that is the best solution to make steel for springs for firearms and sword blades. This technique has been used to produce blades for a long time to improve their mechanical properties, in particular flexibility because the steel produced before the end of $19^{\text {th }}$ century was not suitable itself to make long blades.

The choice of wrought iron to make the billet has been a crucial step. Several forging and heat-treating tests have been made on samples taken from different pieces (railings, gates carriage parts). Tests reveal that many of them are fairly homogenous and not suitable for sword-making, according to Biringuccio that warns against steel that present delaminations (fogliosi) and contaminations of various elements (Sulphur and Phosphor in particular $)^{8}$. Moreover, this explains why the "arms iron and steel" are so expensive in the renaissance period and the Venetian government had strongly enforced the restrictions and control their production, use and commerce for centuries.

The wrought-iron chosen, from a $19^{\text {th }}$ century carriage, has been mixed with a plain carbon steel in alternate layers to produce two starting billets (Fig. 5). The two billets have been forge-welded, cut in many pieces and forge-welded together again several times for a final result of 460 layers on the edge (Fig. 6). The increasing of layer number and several forge-welding stages allow also diffusion of carbon from steel to wrought iron.

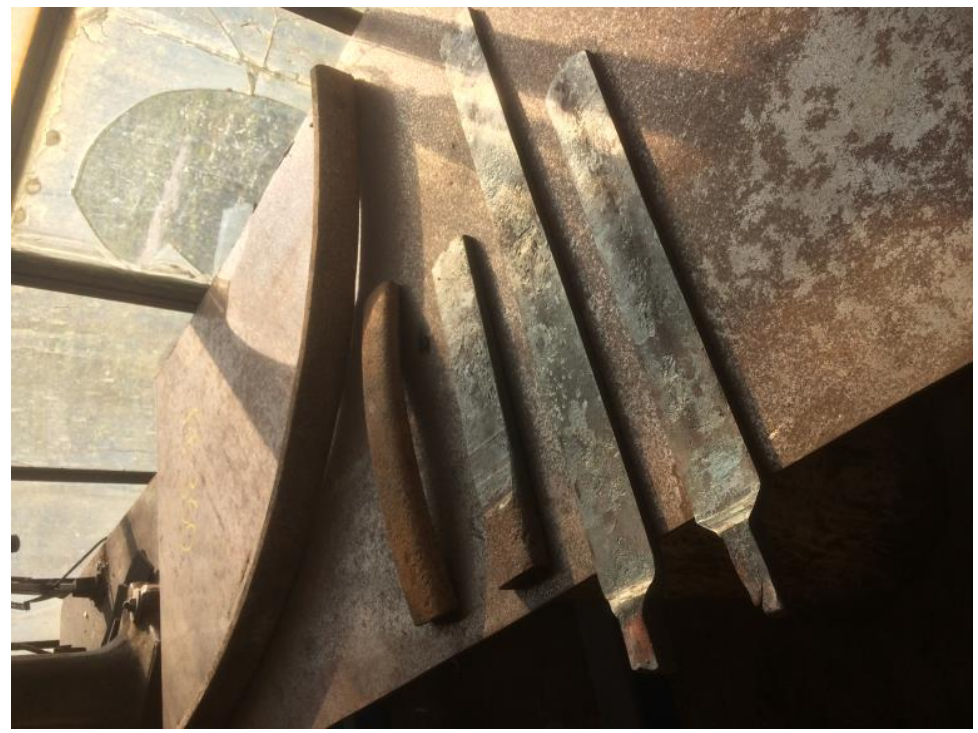

Fig. 5: Pieces from a XIX cent. carriage wheel. Starting material for blade and guard.

8 Biringuccio, De la pirotechnia, 1540, p. 136-137. 


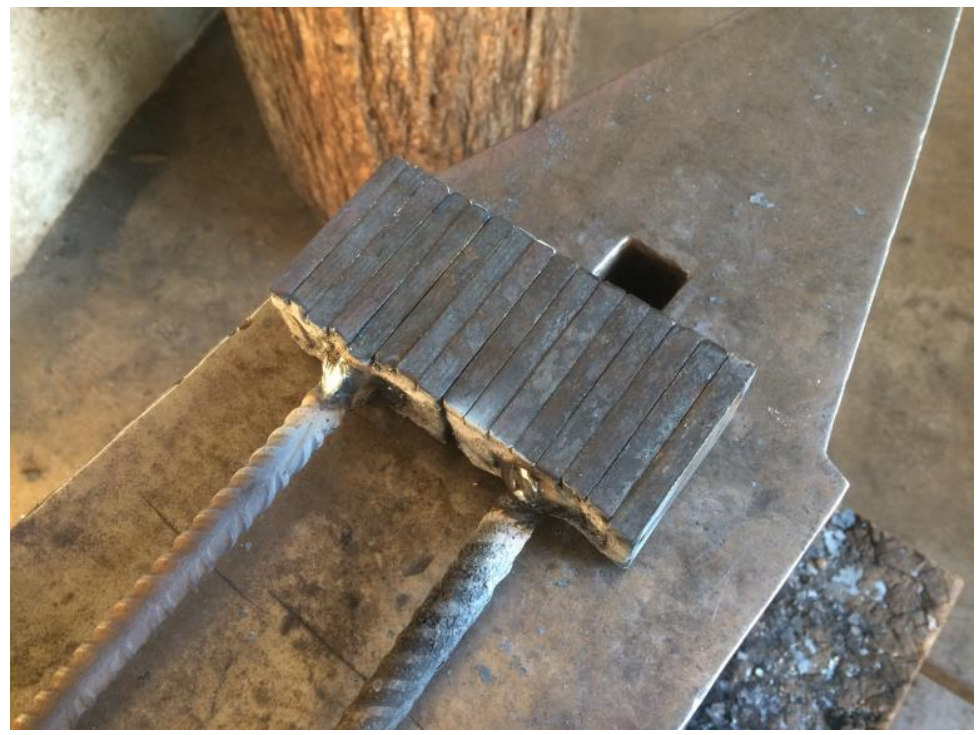

Fig. 6: Billets ready for forge-welding.

\section{II.1.2. Forging the blade}

As explained before, forging has been applied as much as possible to obtain the final geometries of the blade. A technical reason for the use of hot forming is that the pattern of the steel bulk, with its outer "skin" of multilayered steel, will be easily grinded away with the stock removal techniques; on the contrary what we can see from etched metallurgical sections is that this bulk pattern follows even the fullers or the tang form. ${ }^{9}$

The main stages of forging have been done with a power hammer according to the production system of the period when hundred of blades were forged every month in water-powered workshops (we know for example that Andrea Ferara in Belluno owned several water-powered workshops). ${ }^{10}$

The swordsmith, the first master cited by Da Lezze, is the one that forged the blade and heat-treated it; Caino, Gromo, Belluno, Feltre, Ceneda, Serravalle (and many others places) were famous for this stage of production and their masters signed the blades they produced (Da Lezze, 1612; Dal Mas, 1980; Gotti, 2011). ${ }^{11}$

First the billet has been stretched and thinned to obtain the shape of the blade and the proper thickness distribution. The second passage has been the forming of bevel geometry, during this passage the blade has started to get the final curve. Last passages

9 Tonelli et al., "Historical and Metallurgical Characterization of a 'Falchion' Sword"; Williams, The Sword and the Crucible, p. 230-285.

${ }_{10}$ Dal Mas, Spade Bellunesi, p. 6-8.

11 Dal Mas, Spade Bellunesi, p. 24-26; Gotti, Caino, p. 26-37; Da Lezze, Catastico Bresciano, p. 189-192. 
have been: fullers forging (with specific dies under the power-hammer or top-bottom dies on the anvil), tang final shaping, straightening and adjusting curves (Fig. 7).

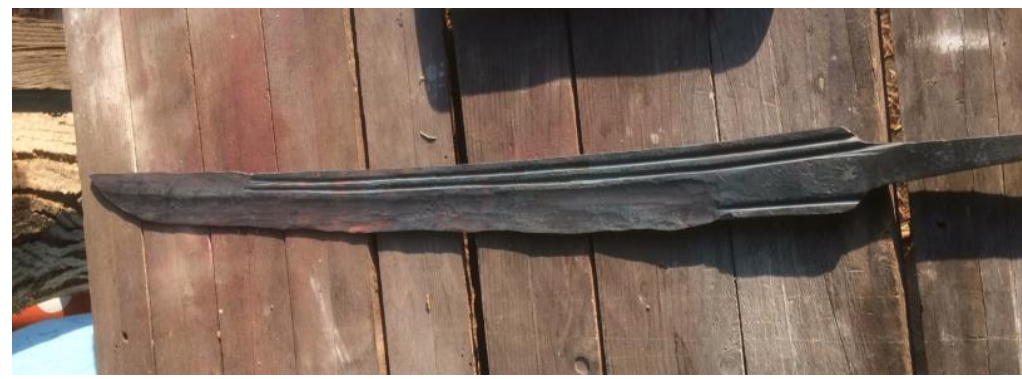

Fig. 7: Freshly forged blade.

\section{II.1.3. Touch marks and decorations}

All the signatures on the blade have been made by hot stamping before and after refined by chiseling. The original one presents many different markings: twelve times the name TOMASO F. on the main fuller and in both sides of the ricasso the CAINO proof mark together with typical decorations of north Italian bladesmiths (half-moon, circles, straight lines on the sides of fullers).

The stamps used on the copy have been made by hand by filing and chiseling: a halfmoon, a circle, a mark inspired by belunese "knots" typical of north Italian sword-makers (that is my main mark), and three stamps to make ZOANE ME FECIT (I was made by Zoane) on the fullers (Fig. 8-9).

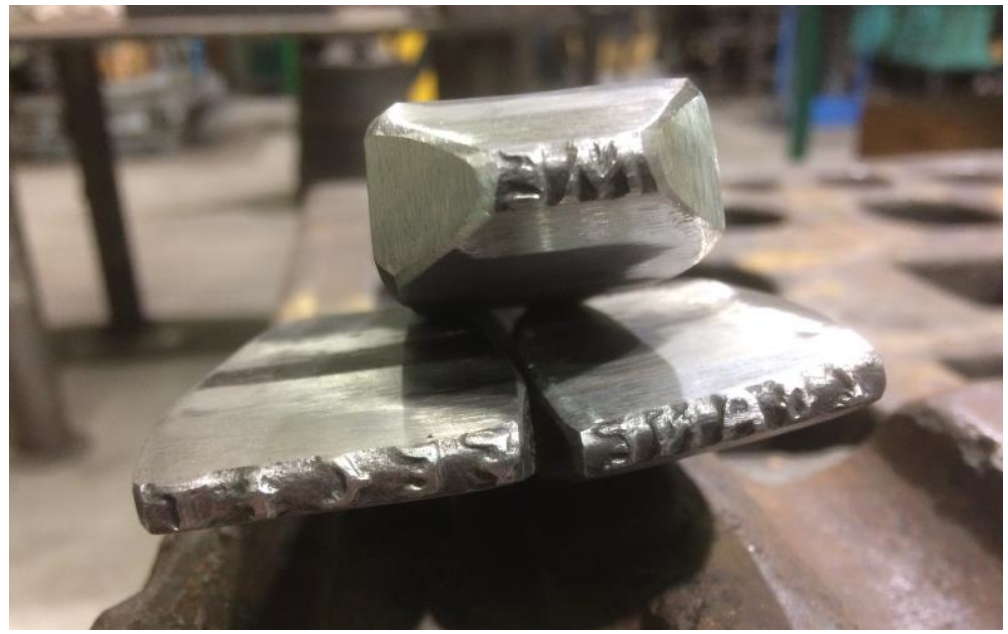

Fig. 8: Touch-marks to stamp ZOANE ME FECIT. 


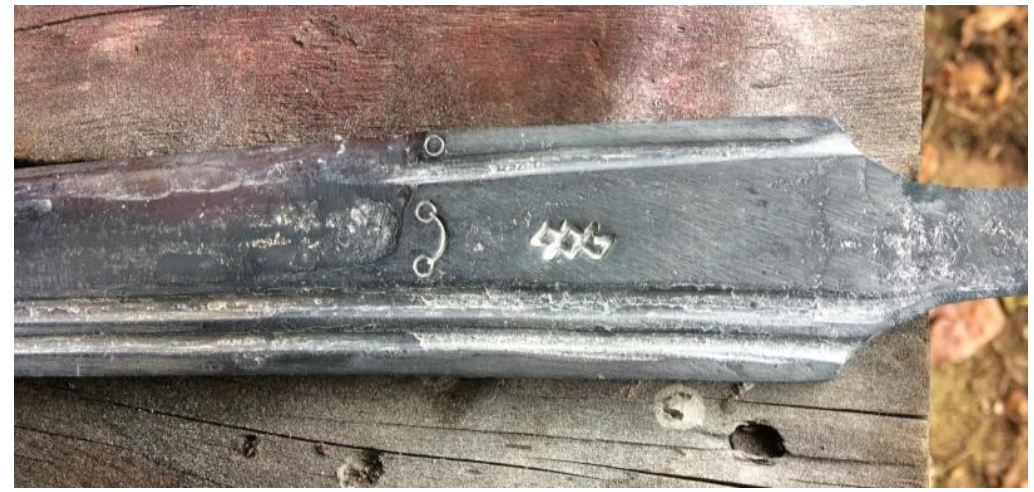

Fig. 9: Signatures on the blade.

\section{II.1.4. Heat treatment}

The average content of carbon measured in the outer layer of the storta studied in Brescia University has been about $0.4-0.5 \%$ with a medium hardness of $50-52$ hrc. $^{12}$ Various tests have been made before making the billet to obtain the same average carbon content and final hardness of the analyzed storta. In particular some samples with a different ratio iron-steel have been made and heat treated in different ways to obtain similar values.

\section{II.1.5. Grinding and polishing}

Grinding and polishing phases has been done by hand with stones, files, sandpapers and natural powders. In particular files of three grades (bastard, 2nd hand, smooth) have been used to obtain regular surfaces and geometries and to make fileworks. As said before the target is to reduce as much as possible these phases; the final result has been a weight loss of $35 \%$ in weight from the starting billet to the final polished blade.

\section{II.2. Pommel and Guard making}

The pommel and guard have been created by forging as well from wrought iron not heattreated according to the metallurgical study on the original storta (Tonelli et $A l, 2016) .{ }^{13}$ A number of top-bottom anvil tools (fullering, cutting, etc., etc.), dies (to curve and dome), spines (to punch) tongs and hammers have been especially made to forge these parts.

In particular the pommel has been made by two half forge-welded together like the analyzed original. On every half, before welding, a central fuller was made as a "guide" for the tang hole which was finally made by hot punching.

The wrought iron used to make the pommel came from 17-18 ${ }^{\text {th }}$ century balaustrade bars fairly homogeneous and forge-welded together to make the starting billet. During hot

\footnotetext{
12 Tonelli et al., "Historical and Metallurgical Characterization of a 'Falchion' Sword”.

13 Ibid.
} 
working operations the "poor" quality of the wrought iron has caused some evident delaminations easy to see on some original arms and armour too (Fig. 10).

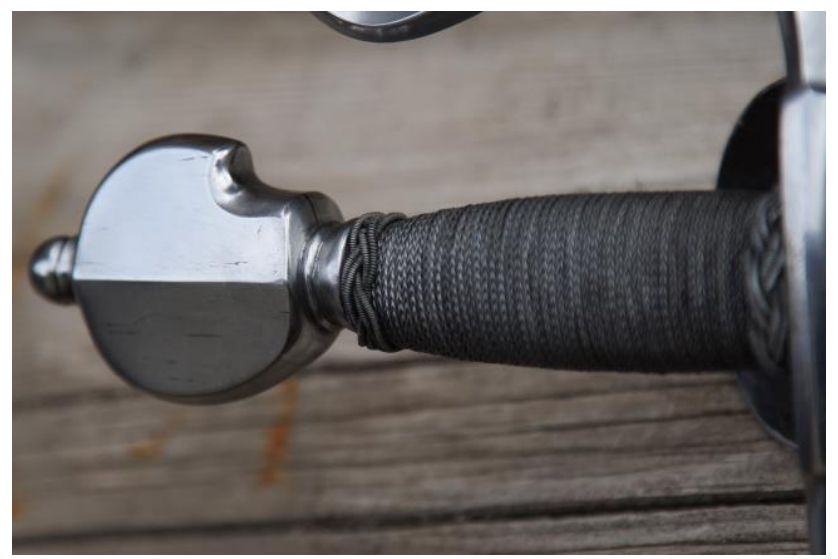

Fig. 10: Pommel detail, it is possible to observe delaminations and inclusions. CPhoto Alberto Dalla Valle.

The guard was produced from the same carriage wheel that was used as the source for the pieces of the blade. This iron is much more homogeneous than the one used for the pommel but some delaminations became visible too during forging (Fig. 11).

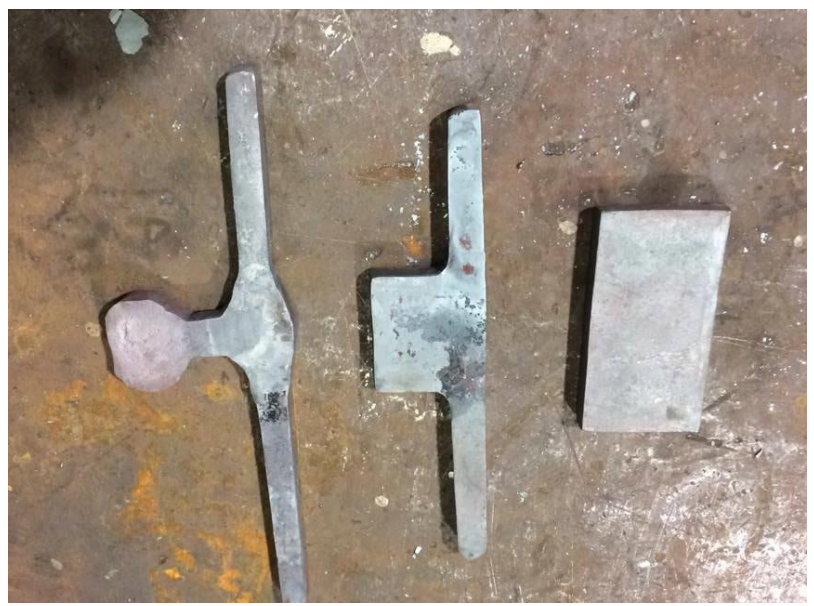

Fig. 11: Some forging stages of guard.

All parts of the guard have been forged out from a single rectangular piece, so no forgewelding has been applied. Techniques used have been cutting, fullering, hot punching, bending and stretching. For the grinding-polishing stages, the techniques have been the same used for the blade, in particular tiny needle files for fileworks refining (Fig. 12). 


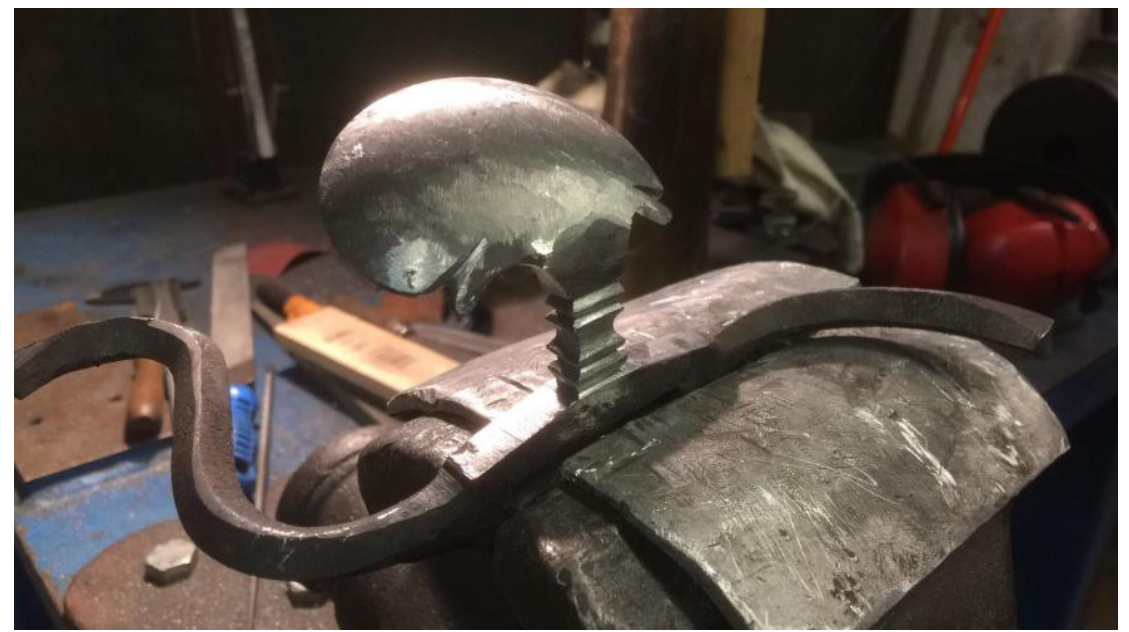

Fig. 12: Guard during file polishing.

\section{II.3. Handle making}

The handle has been made from a single piece of ash wood wrapped with iron wire. To make the central cavity for the tang, the wood has been first drilled and then the hole adapted (with the same shape of the tang) with a hot spine. The wood has been then wrapped with iron braid held in place by two Turk's heads knots on the ends. The Turk's head is a classic iron wire pattern in use on arms handles from the sixteenth century, and its main function was to avoid the wood handle splitting caused by the tang (Fig. 13).

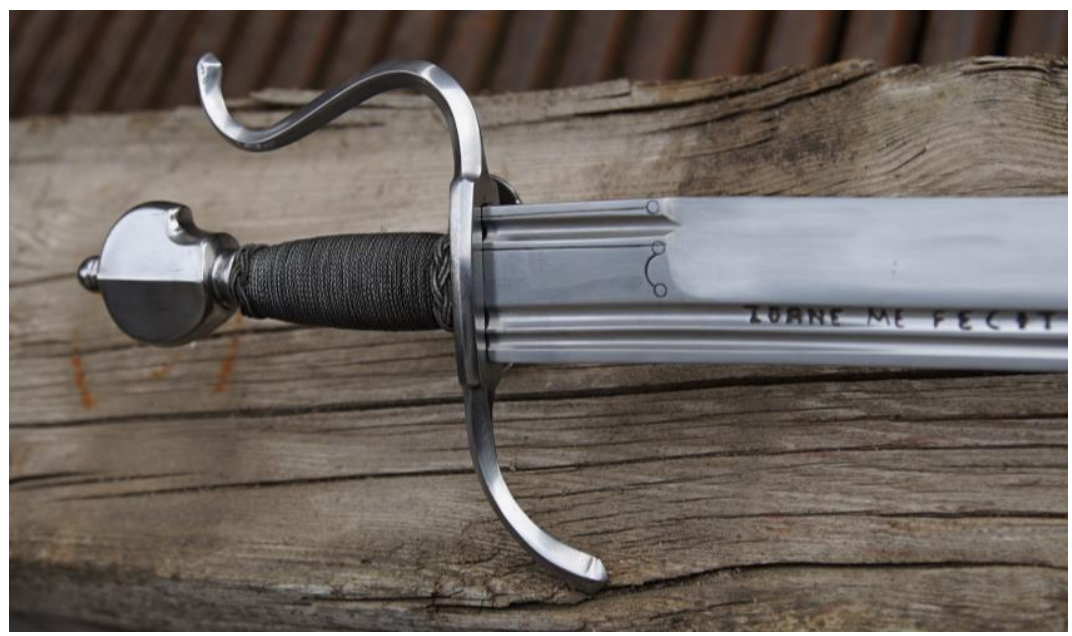

Fig. 13: Handle detail. CPhoto Alberto Dalla Valle. 


\section{CONCLUSIONS}

The result of the project has been a sword that is really close to the original on geometries forms and weights distribution (there is a difference of 4 grams between the original and the copy) (Fig. 14-15).

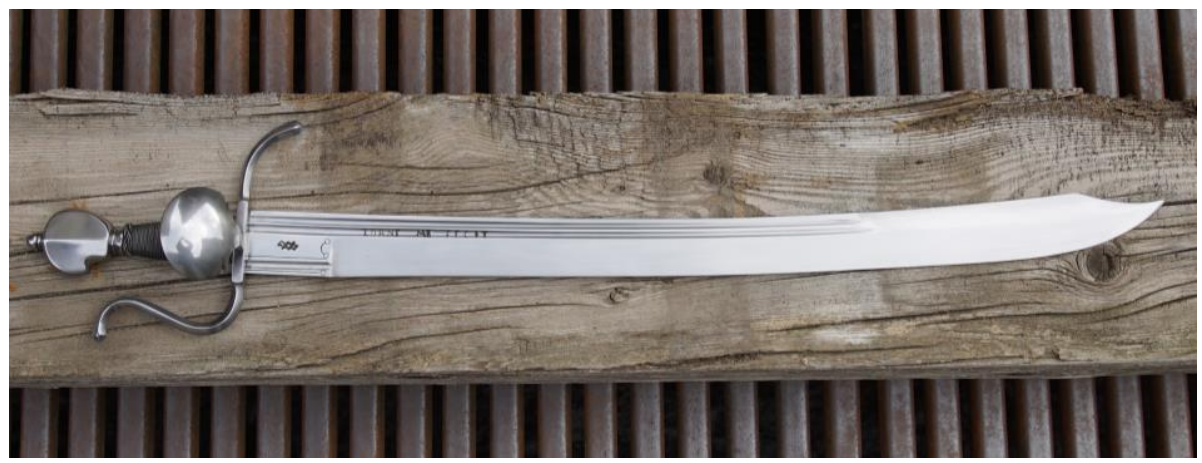

Fig. 14: Sword completed. CPhoto Alberto Dalla Valle.

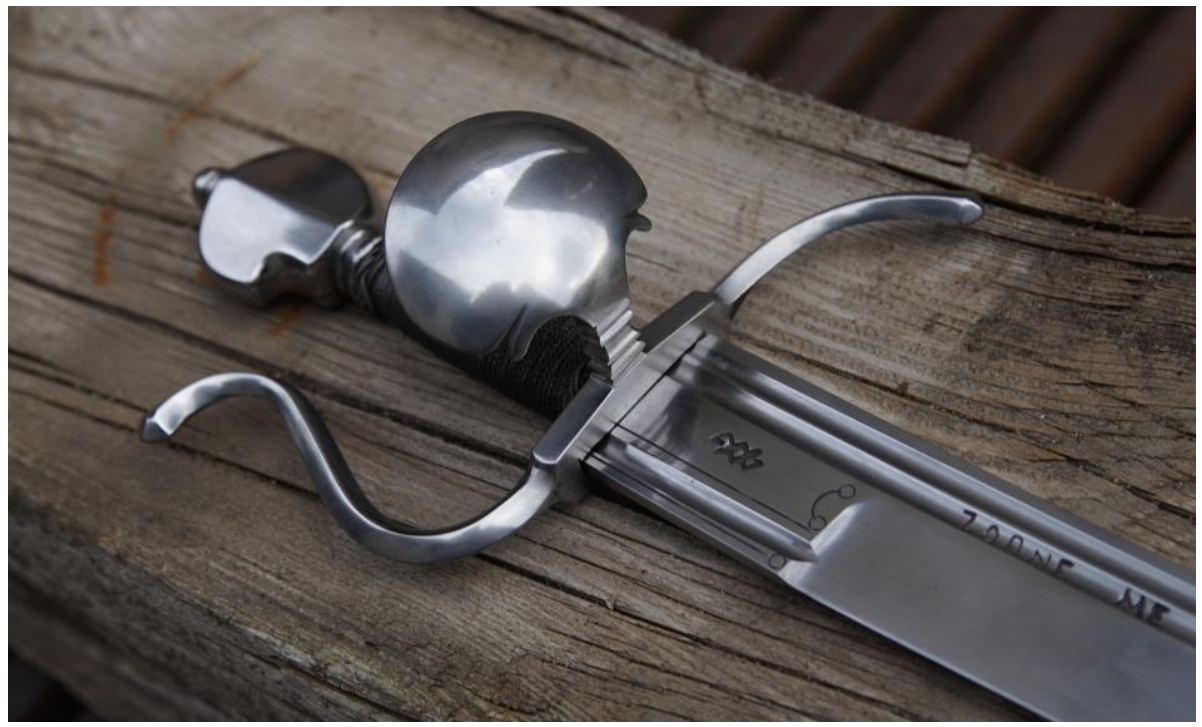

Fig. 15: Sword completed. OPhoto Alberto Dalla Valle.

It is certainly a satisfying result, but this sword should be considered only a starting point for further research about traditional techniques of sword-making.

To explain better to the visitors the making process of the sword and to show more about the art of sword-making in the sixteenth century a video-documentary has been produced (video-maker Alberto Dalla Valle).

Additionally, samples of the main production stages for all parts have been made alongside the sword copy and displayed with it to complement the understanding of its making process. 


\section{Acknowledgments}

This work has been possible thanks to MAM (Martial Arts Museum, Botticino), the Committee for Hema Minsk 2019 and in particular to Roberto Gotti who has strongly encouraged this project. Studies and replica: Giovanni Sartori. Editing: Iason-Eleftherios Tzouriadis and Daniel Jaquet. A short film documenting the project is on display and can be viewed through a QR code of the exhibition catalogue ${ }^{14}$.

\section{BIBLIOGRAPHY}

\section{IV.1. Primary sources}

Biringuccio, Vannoccio, De la pirotechnia, 1540. A cura di Adriano Carugo (Milano: Il Polifilo, 1977).

Da Lezze, Giovanni, Catastico Bresciano, 1612. Ristampa anastatica a cura della Biblioteca Civica Queriniana (Brescia: Casa Editrice F. Apollonio \& C.: 1969).

Dal Mas, Mario, Spade Bellunesi: “... supra royam fluminis Ardi” (Belluno: Comitato Marangoni, 1980).

Gotti, Roberto, Caino (Verona: Punto Marte, 2011).

Gotti, Roberto, Daniel Jaquet and Iason-Eleftherios Tzouriadis, European Martial Arts, exhibition catalog (Dello: Grafiche Renzini, 2019).

Gaibi, Agostino, “Un manoscritto del '600 'L'Arte Fabrile' di Antonio Petrini”, Armi Antiche (1962), 111-139.

Tonelli, Giovanna et al., "Historical and Metallurgical Characterization of a 'Falchion' Sword Manufactured in Caino (Brescia, Italy) in the Early 17th Century A.D", Journal of The Minerals, Metals \& Materials, Volume 68, Issue 8 (2016), 2233-2249.

Williams, Alan, The Sword and the Crucible: A History of the Metallurgy of European Swords up to the XVI century (Leiden: Brill, 2012).

14 Gotti, Jaquet and Tzouriadis, European Martial Arts. 